\title{
Al Qur'an Healing Therapy Increases Letdown Reflex in Breastfeeding Mothers
}

\author{
Intan Mutiara Putri ${ }^{1}$, Fitria Siswi Utami ${ }^{2}$ \\ \{intan.mutiaraputri@unisayogya.ac.id $\left.{ }^{1}\right\}$ \\ Faculty of Health Sciences' Aisyiyah University Yogyakarta Indonesia ${ }^{1,2}$
}

\begin{abstract}
Breast milk is the best food source for the baby's growth and development. However, in practice, not all mothers provide exclusive breastfeeding for up to 6 months for various reasons, including the reduced of breast milk production. The relaxation method used is non-pharmacological therap. This study aims to determine the effect of AlQuran Healing relaxation therapy on Letdown Reflex in breastfeeding mothers. This research method was a quasi-experimental one group pre-posttest design. Purposive nonprobability sampling technique was used for sample selection. The research samples used were 15 breastfeeding mothers. The first data collection tool was a questionnaire on the demographic data of the respondents and the second was about the Letdown Reflex assessment. Al-Quran Healing therapy intervention was given for three days with a Letdown reflex assessment before and after the intervention administration. Letdown reflex assessment before the intervention showed that there were 5 respondents (33.3\%) with a poor category and 10 respondents $(66.7 \%)$ with a good category. After the intervention, it was found that all mothers, that were 15 respondents $(100 \%)$, had a good Letdown reflex assessment. The results of the analysis showed a p-value of $0.001(<0.005)$, which meant that there was an effect of giving Al-Quran Healing therapy on the frequency of Letdown Reflex. There was a difference between the letdown reflex before and after the intervention.
\end{abstract}

Keywords: Therapy, Al-Quran healing, letdown reflex, breastfeeding mothers

\section{Introduction}

The Indonesia government strongly supports the exclusive breastfeeding movement. This is indicated by the Decree of the Minister of Health of the Republic of Indonesian concerning exclusive breastfeeding for infants in Indonesia [1]. According to the Indonesia Pediatric Society, these two policies are an effort to regulate various matters regarding exclusive breastfeeding including the application of 10 Steps to Successful Breastfeeding in all lines of health services in Indonesia [2]. In the celebration of World Breastfeeding Week 2017, breastfeeding is echoed as one of the keys to the success of the Sustainable Development Goals (SDGs) in 2030. All parties are invited to work together to support and participate in breastfeeding [3].

Various studies mention that exclusive breastfeeding provides benefits not only for babies but also for breastfeeding mothers. The many benefits of exclusive breastfeeding are not in line with the targets of exclusive breastfeeding. This is indicated by the achievement of $33.5 \%$ which is still far from the target of $80 \%$ [4]. Various factors are associated with exclusive breastfeeding, including the tradition of feeding babies in families and communities, inadequate 
sources of information from husbands, families, and health workers, the mother's decision to provide complementary feeding when the baby is fussy with the perception of insufficient breast milk to meet the baby's needs [5].

Every mother is obliged to provide breast milk except for mothers or babies who have special conditions such as a dead baby or a mother who is separated from her baby. This shows that breast milk is the right of every baby born. Breast milk is known as the best food source for the baby's growth and development. However, in practice, not all mothers provide exclusive breastfeeding for up to 6 months for various reasons, including the reduced of breast milk production. One technique that can be used to increase breast milk production is to stimulate the mother's body's decline reflex. The relaxation method used is non-pharmacological therapy, which theoretically is a method that can be used to stimulate breastfeeding reflexes to increase breast milk production. The results of other studies indicated that one of the factors related to mother's breastfeeding behavior was maternal self-efficacy. This self-efficacy is influenced by the mother's perception of the adequacy of breast milk produced to meet the nutritional needs of the baby [6].

Based on interviews conducted with several previous mothers, they said they did not know about the term letdown reflex. After being given an explanation of the signs of letdown reflex, they finally understood. Two mothers said that while breastfeeding they felt the letdown reflex was quite good, 3 more people said they didn't really feel it and 4 others said they didn't really pay attention to it. Efforts are made to increase the letdown reflex, such as eating enough before breastfeeding, listening to music and the Quran. A mother tells her experience of her first child who has not been able to breastfeed properly, is currently her second child and hopes to provide exclusive breastfeeding. This study aims to determine the effect of Al-Quran Healing relaxation therapy on Letdown Reflex in breastfeeding mothers.

\section{Literature Review}

Letdown reflex is a sign that the milk is ready to flow so that the breastfeeding process is easier. The signs of Letdown reflex are ticklish or tingling feelings in the breasts, pressure on the breasts, breasts feel full, the mother feels thirsty and even milk drips into the breast that the baby does not suck. Letdown reflex can occur when the mother hears, sees or even thinks of her baby. Letdown reflex is triggered by touching the breast in the nipple area [7]

There was a study in India on the effect of back massage on the increase of letdown reflex in post-cesarean section mothers. The research was a quantitative quasi- experimental research with non-equivalence control group design. Purposive non-probability sampling technique was used for sample selection. There were 10 samples for the experimental group and 10 samples for the control group from two different settings. At the pre-assessment, in the experimental and control groups, $30 \%$ of mothers had poor Letdown reflex and $70 \%$ had excellent Letdown reflex. The results of the assessment showed that there was a significant increase in the Letdown reflex in the experimental group [8].

Other studies on the effect of oxytocin massage on letdown reflex were conducted in Indonesia. This quasi-experimental research employed a pretest-posttest one-group design. The samples in this study were all women who were giving birth as many as 30 respondents. The technique of collecting data was by giving a questionnaire before doing the massage and after the massage. The results showed that before the stimulating massage of oxytocin, 20 mothers $(66.7 \%)$ had less active letdown reflex and 10 mothers $(33.3 \%)$ had active letdown reflex. After 
doing oxytocin-stimulating massage, 19 respondents $(63.3 \%)$ had increased active letdown reflex and 11 respondents $(36.7 \%)$ had less active letdown reflex. The results obtained a $p$ value $=0.00(<0.005)$ which meant that there was an effect of oxytocin-stimulating massage on letdown reflex in postpartum mothers [4].

Reflexion sound that is played Qur'an can help reduce tension or stress. Endorphin hormones naturally be active with reduced stress, a sense of calm and relaxed it would appear to be able to switch maternal anxiety and psychological tension concept of relaxation therapy Qur'an is doing distraction to the feelings that interfere with breastfeeding mothers in the process, for example anger, emotionally unstable, anxious, or fearful [5].

\section{Method}

This study employed a quasi-experimental one group pre-posttest design. Purposive nonprobability sampling technique was used for sample selection. The research samples were 15 breastfeeding mothers. Criteria for respondents in this study were breastfeeding mothers with experiences of first, second or more children. The first data collection tool was a questionnaire on the demographic data of the respondents and the second was about the Letdown Reflex assessment. The intervention of Al-Quran Healing therapy with a duration of 30 minutes was given for three days with a Letdown reflex assessment before and after giving the intervention.

Surah Ar-Rahman is the 55th chapter which consists of 78 verses, in which there is a repetition of the verse 31 times which flows so beautifully and soothes the heart, this verse which means "then which blessings of your Lord do you deny?" The verse describes mercy. Allah to His servants, by giving unlimited favors to His servants both in this world and in the hereafter. The provision of healing Al-Quran therapy using the recording of the letter Arrahman. The recording of the Surah Al-Rahman is listened to for 30 minutes before breastfeeding. Therapy is carried out for 3 days. The letdown reflex assessment was carried out before doing the first therapy and was reassessed on the third day using semi-structured questions about the signs of letdown reflex such as a pinching feeling in the breast, the breast feeling full and milk coming out of the side of the breast that is not being used. pump with. This response was assessed with the guidelines given, namely Strong feeling was given a score of 3, Medium feeling was given a score of 2, Mild feeling was given a score of 1 , the overall score was interpreted as follows 3 as a bad letdown reflex, 4-8 as a good letdown reflex, 9 as a reflex very good letdown. Data analysis used was univariate with frequency distribution of respondent characteristics and letdown reflex assessment before and after intervention. Bivariate data analysis was carried out to determine the difference in the letdown reflex assessment before and after the Qur'an healing intervention was given.

\section{Result and Discussion}

\subsection{Results}

The characteristics of the respondents indicated that 14 mothers $(93.3 \%)$ aged 20-35 years, 11 respondents $(73.3 \%)$ had bachelor degree, 9 respondents $(60 \%)$ did not work. Mothers' characteristics based on parity showed that 7 respondents $(46.7 \%)$ with multiparous, and 12 respondents $(80 \%)$ had a history of normal delivery. The characteristics of babies based on age 
showed that 9 respondents $(60 \%)$ had a baby aged $1-2$ months, 9 respondents $(60 \%)$ had male baby and 13 respondents $(86.6 \%)$ had a history of birth weight between 2500-4000 grams.

Table 1. Frequency distribution of respondent characteristics $(n=15)$

\begin{tabular}{|c|c|c|c|}
\hline No & Characteristics & $\mathbf{n}$ & $\%$ \\
\hline \multirow[t]{3}{*}{1} & Age & & \\
\hline & $20-35$ years & 14 & 93,3 \\
\hline & $36-45$ years & 1 & 6,7 \\
\hline \multirow[t]{3}{*}{2} & Education & & \\
\hline & Low & 4 & 26,7 \\
\hline & High & 11 & 73,3 \\
\hline \multirow[t]{3}{*}{3} & Occupation & & \\
\hline & Unemployed & 9 & 60,0 \\
\hline & Employed & 4 & 40,0 \\
\hline \multirow[t]{3}{*}{4} & Birt history & & \\
\hline & Normal & 12 & 80,0 \\
\hline & Sectio caesarea & 3 & 20,0 \\
\hline \multirow[t]{4}{*}{5} & Parity & & \\
\hline & Primipara & 5 & 33,3 \\
\hline & Multipara & 7 & 46,7 \\
\hline & Grandemultipara & 3 & 20 \\
\hline \multirow[t]{4}{*}{6} & Age of the baby & & \\
\hline & $1-2$ month & 9 & 60,0 \\
\hline & 3-4 month & 3 & 20,0 \\
\hline & 5-6 month & 3 & 20,0 \\
\hline \multirow[t]{3}{*}{7} & Sex & & \\
\hline & Female & 6 & 40,0 \\
\hline & Male & 9 & 60,0 \\
\hline \multirow[t]{4}{*}{8} & Newborn weight & & \\
\hline & $<2500$ gram & 1 & 6,7 \\
\hline & $2500-4000$ gram & 13 & 86,7 \\
\hline & $>4000$ gram & 1 & 6,7 \\
\hline
\end{tabular}

Table 2. Frequency distribution of letdown reflex assessments before and after intervention $(n=15)$

\begin{tabular}{lcccc}
\hline Letdown reflex & \multicolumn{2}{c}{ Before intervention } & \multicolumn{2}{c}{ After intervention } \\
& $\mathrm{n}$ & $\%$ & $\mathrm{n}$ & $\%$ \\
\hline $\mathrm{Bad}$ & 5 & 33,3 & 0 & 0 \\
Good & 10 & 66,7 & 15 & 100 \\
\hline
\end{tabular}

Letdown reflex assessment before the intervention showed that there were 5 respondents $(33.3 \%)$ with a poor category and 10 respondents $(66.7 \%)$ with a good category. After the intervention, it was found that all mothers, that were 15 respondents $(100 \%)$, had a good Letdown reflex assessment. The results showed that there was no decrease in the Letdown reflex value before the intervention and after the intervention, which meant that all respondents experienced an increase in the Letdown reflex value.

Table 3. The results of the analysis of the effect of healing Al-Quran therapy on letdown reflex in breastfeeding mothers

\begin{tabular}{ccc}
\hline Letdown reflex & Mean & p-value \\
\hline
\end{tabular}




\begin{tabular}{lll}
\hline Before intervention & 0,00 & 0,001 \\
After intervention & 8,00 & \\
\hline
\end{tabular}

The results obtained a p-value: $0.001(<0.05)$, which meant that there was a difference in the Letdown reflex value before and after the intervention. Healing Qur'an therapy affects the letdown reflex in nursing mothers.

\subsection{Discussion}

In the mother's body, there are two hormones that directly affect the breastfeeding process, that are prolactin and oxytocin. A number of other hormones, such as estrogen, are indirectly involved in ion loss [9]. When the baby is breastfed, sensory impulses travel from the nipple to the brain. In response, the anterior lobe of the pituitary gland secretes prolactin and the posterior lobe secretes oxytocin. Oxytocin makes myoepithelial cells around the alveoli contract. This allows the breast milk, which collects in the alveoli, to flow and fill the channels [10]. The oxytocin reflex is also sometimes called the "let-down reflex" or the "milk ejection reflex." Oxytocin is produced faster than prolactin. It keeps the milk that is already in the breast flowing for current breastfeeding, and helps the baby get breast milk easily. Oxytocin starts working when the mother expects to breastfeed and when the baby is breastfeeding. Reflex becomes conditioned on the mother's sensations and feelings, such as touching, kissing or seeing her baby, or hearing her baby cry, or thinking about it with love. If a mother is experiencing severe pain or emotional distress, the oxytocin reflex can be inhibited, and the breast milk suddenly stops flowing properly. If she gets support and feels helped to feel comfortable and let the baby continue to breastfeed, the milk will flow again [7].

The letdown reflex is also known as the flow reflex or oxytocin reflex or the release of breast milk. The letdown reflex is greatly influenced by the presence of the hormone oxytocin. This hormone has increased significantly since the start of pregnancy. Postpartum mothers, on the first and second days, are still recovering their genital organs (early puerperium) so that mothers still tend to focus on recovering themselves [4]. The factor that obstructs the emergence of letdown reflex is stress. Stress is caused by biological factors (reproductive organ recovery) and psychological factors (taking in phase). When breastfeeding mother is stressed, there will be a blockade of the letdown reflex. This is due to the release of adrenaline (epinephrine) which causes vasoconstriction of the alveoli blood vessels, so there is a little hope that oxytocin to reach the target of myoepithelial organ. Since the letdown reflex is incomplete, there will be a buildup of milk in the alveoli, which clinically appears enlarged breasts. Large breasts can result in abscesses, failure to breastfeed and pain. This pain will lead to stress again for the mother so that the stress will increase. Another study conducted in India regarding letdown reflex with different interventions, that was the provision of back massage, concluded that there was a significant increase in the Letdown reflex value in the experimental group compared to the control group [8]. The results showed that there were differences. The concept of Al-Qur'an relaxation therapy is to distract the feelings that disturb the mother during the breastfeeding process, such as anger, unstable emotions, anxiety, or fear. The sound of reflection played by the Koran can help reduce tension or stress. Endorphin hormones naturally become active with reduced stress, a sense of calm and relaxation will appear to be able to divert maternal anxiety and psychological tension. The concept of Koran relaxation therapy is to disturb feelings that disturb the mother in the breastfeeding process, for example anger, emotionally unstable, anxious, or fear, which would create a good letdown reflex. Based on the results of this study, it is hoped that the Koran healing therapy can be an alternative new method to support the 
success of exclusive breastfeeding for breastfeeding mothers. The results of this study cannot be generalized to all breastfeeding mothers, because the sample size in this study is small.

\section{Conclusion}

There is a difference in the letdown reflex before and after the intervention of the Al Qur'an healing for breastfeeding mothers. Healing Qur'an therapy affects the letdown reflex in nursing mothers.

\section{Acknowledgements}

The researcher would like to express her gratitude to the Ministry of Research and Technology Indonesia Research and Innovation Agency and the University of 'Aisyiyah Yogyakarta who have provided grant funding for this research.

\section{References}

[1] "Kepmenkes No. 450 Th. 2004 Tentang Pemberian ASI.pdf.” Accessed: Nov. 13, 2020. [Online]. Available: $\quad$ https://aimi-asi.org/storage/app/media/pustaka/Dasarasar\%20Hukum/Kepmenkes\%20No.\%20450\%20Th.\%202004\%20Tentang\%20Pem berian\%20ASI.pdf.

[2] "IDAI - Nilai Nutrisi Air Susu Ibu." https://www.idai.or.id/ artikel/klinik/asi/nilai- nutrisi-air-susu-ibu (accessed Nov. 13, 2020).

[3] "Profil-Kesehatan-Indonesia-tahun-2017.pdf." Accessed: Nov. 13, 2020. [Online]. Available:https://www.kemkes.go.id/resources/download/pusdatin/profil- $\quad$ kesehatanIndonesia/Profil-Kesehatan-Indonesia-tahun-2017.pdf.

[4] P. Wulandari and P. A. Fajrin, "Pengaruh Pijat Stimulasi Oksitosin Terhadap Let Down Reflek Pada Ibu Post Partum Di Rumah Bersalin Mardi Rahayu Kalibanteng Semarang," vol. 3, no. 2, p. 7.

[5] E. Rilla, H. Ropii, and A. Sriati, "Terapi Murottal Efektif Menurunkan Tingkat Nyeri Dibanding Terapi Musik pada Pasien Pascabedah,” Jurnal Keperawatan Indonesia, vol. 17, pp. 74-80, Jul. 2014, doi: 10.7454/jki.v17i2.444.

[6] K. L. Tan, "Factors associated with exclusive breastfeeding among infants under six months of age in peninsular malaysia," International Breastfeeding Journal, vol. 6, no. 1, p. 2, Feb. 2011, doi: $10.1186 / 1746-4358-6-2$.

[7] "WHO | Infant and young child feeding: Model Chapter,"

WHO. http://www.who.int/nutrition/publications/infantfeeding/9789241597494/en/ (accessed Nov. 27, 2020).

[8] "(PDF) The Effect of Back Massage on Let Down Reflex among Mothers Who Had Undergone Cesarean Section." https://www.researchgate.net/publication/ 309179454_The_Effect_of_Back_Massage_on_Let_Down_Reflex_among_Mothers _Who_Had_Undergone_Cesarean_Section (accessed Aug. 13, 2020).

[9] "laranc.pdf." Accessed: Nov. 27, 2020. [Online]. Available: https://iums.ac.ir/files/vch/files/laranc.pdf.

[10] D. T. Ramsay, J. C. Kent, R. A. Owens, and P. E. Hartmann, "Ultrasound imaging of milk ejection in the breast of lactating women," Pediatrics, vol. 113, no. 2, pp. 361-367, Feb. 2004, doi: 10.1542/peds.113.2.361. 